Submitted: 14.11.2013 Accepted: 29.11.2013

Słowa kluczowe ultrasonografia, przedwczesne dojrzewanie płciowe, anatomia, thelarche, pubarche, adrenarche

Key words

sonography, precocious puberty, anatomy, thelarche, pubarche, adrenarche

\section{Diagnostyka ultrasonograficzna narządów jamy brzusznej w przypadku przedwczesnego dojrzewania płciowego u dziewcząt}

\author{
Sonography of abdominal organs in precocious puberty \\ in girls
}

Maciej Mazgaj

Zakład Diagnostyki Obrazowej, Dziecięcy Szpital Kliniczny w Lublinie, Lublin, Polska Correspondence: Maciej Mazgaj, Zakład Diagnostyki Obrazowej, Dziecięcy Szpital Kliniczny, ul. Chodźki 2, 20-093 Lublin,e-mail:maciejmazgaj@gmail.com,tel.: +48 817418447

\section{Streszczenie}

Przedwczesne dojrzewanie płciowe stanowi istotny problem kliniczny ze względu na implikacje psychologiczne, zdrowotne, a także odnoszące się do płodności dotkniętych nim dziewcząt. Samoakceptacja, akceptacja w grupie rówieśniczej, wczesne macierzyństwo, przyszła płodność - to tylko niektóre z zagadnień związanych z dojrzewaniem płciowym, którego zaburzenia negatywnie wpływają na rozwój osobowości i zdrowie człowieka. Rolą diagnostyki obrazowej jest ustalenie przyczyn przedwczesnej aktywacji procesu dojrzewania, zdefiniowanie zmian odpowiadających za nieprawidłową produkcję hormonów płciowych oraz będących skutkiem istniejących zaburzeń, a także uwidocznienie procesów jedynie naśladujących objawy przedwczesnego dojrzewania. Spośród wszystkich dostępnych metod obrazowania ultrasonografia, ze względu na bezpieczeństwo, dostępność, powtarzalność i niski koszt, wydaje się najlepszą metodą służącą do oceny piersi i narządów wewnętrznych pacjentek z objawami przedwczesnego dojrzewania zarówno w procesie wstępnej diagnostyki, jak i w monitorowaniu przebiegu leczenia. W artykule oprócz zagadnień dotyczących techniki badania ultrasonograficznego omówiono jego rolę w przypadku przedwczesnego dojrzewania płciowego u dziewcząt, opisano prawidłowe parametry narządów odgrywających istotną rolę w procesie dojrzewania, a także przedstawiono cechy zmian będących przyczyną lub skutkiem zaburzeń hormonalnych.

\begin{abstract}
Precocious puberty constitutes a significant clinical problem due to psychological implications and health concerns as well as consequences associated with girls' fertility. Selfacceptance, peer approval, early motherhood and future fertility - these are only a few issues associated with puberty, the disorders of which may have a negative influence on personality and health. The role of imaging is to determine the causes of early activation of the puberty process, to identify lesions responsible for abnormal sex hormone production and those which are the result of underlying hormonal disorders as well as to diagnose the processes which only mimic symptoms of precocious puberty. Out of all available imaging methods, sonography, thanks to its safety, availability and low cost, seems to be the best method to assess the breasts and internal organs of patients manifesting symptoms of precocious puberty both in early diagnosis and follow-up examinations. Apart from the technique of performing ultrasound examinations, the paper also explains its role in precocious puberty in girls, describes correct parameters of the organs which play the most significant role in the process of puberty as well as presents the features of changes responsible for or resulting from hormonal disorders.
\end{abstract}




\section{Wstęp}

Przedwczesnym dojrzewaniem płciowym (PDP) nazywa się rozwój drugorzędowych cech płciowych przed 8. rokiem życia. Występuje z częstością 1:5000 - 1:10 000 i jest 3-23 razy częstsze u dziewcząt niż u chłopców ${ }^{(1)}$. Problem ten może pojawiać się na skutek zbyt wczesnej aktywacji fizjologicznych mechanizmów odpowiedzialnych za dojrzewanie, najczęściej bez uchwytnej przyczyny lub ze względu na zmiany w centralnym układzie nerwowym. Może też być reakcją na hormonalną stymulację zewnątrzustrojową (np. pokarm, leki, kosmetyki) lub wewnątrzustrojową (np. patologie jajników, nadnerczy).

Wczesne rozpoznanie i leczenie PDP jest istotne ze względu na konsekwencje emocjonalne (akceptacja w grupie rówieśniczej, problemy wieku dojrzewania, wczesna płodność i macierzyństwo) i zdrowotne (wczesne zakończenie wzrastania, obniżona płodność w wieku dojrzałym) ${ }^{(2)}$. Algorytmy diagnostyczne PDP obejmują panele badań hormonalnych, genetycznych i obrazowych.

Standardowym badaniem obrazowym rozszerzającym badanie przedmiotowe pacjenta jest badanie ultrasonograficzne (USG) piersi i jamy brzusznej, mające na celu uwidocznienie istniejących zmian będących przyczyną (np. guzy jajnika, nadnerczy) i skutkiem (przyspieszony rozwój wewnętrznych narządów płciowych - macicy i jajników) przedwczesnego dojrzewania.

\section{Technika badania USG w przedwczesnym dojrzewaniu płciowym}

Aby prawidłowo wykonać badanie USG dziecka, należy dysponować aparatem ultrasonograficznym, który oprócz badania w standardowej, dwuwymiarowej projekcji w odcieniach szarości umożliwia również ocenę przepływów naczyniowych (opcje kolorowego dopplera, dopplera mocy, dopplera spektralnego). Często wykorzystuje się obrazowanie harmoniczne, poprawiające jakość uzyskanego obrazu.

Aparat ten ponadto musi umożliwiać ocenę wielkości badanych struktur (pomiar długości, objętości) oraz udokumentowanie przeprowadzonego badania w formie wydruków z drukarki wideo lub zapisanych w pamięci aparatu (bądź komputera sprzężonego $\mathrm{z}$ aparatem) zdjęć i filmów w formie cyfrowej.

Brak współpracy dziecka, niepokój ruchowy oraz płacz niejednokrotnie znacznie utrudniają badanie. Funkcja cine z możliwością powrotu do poprzednio uzyskanych przekrojów po zatrzymaniu obrazu w dużej mierze znosi te niedogodności.

Do badania USG jamy brzusznej dziecka, a szczególnie do oceny narządów miednicy mniejszej, wykorzystuje się głowice o szerokim spektrum częstotliwości oraz o różnej wielkości. Zasadą jest, iż u młodszych dzieci używa się głowic mniejszych, o wyższej częstotliwości niż u dzieci starszych.

\section{Introduction}

Precocious puberty (PP) is a development of secondary sex characteristics before the age of 8 . Its incidence constitutes 1:5000-1:10 000 and occurs 2-23 times more frequently in girls than in boys ${ }^{(1)}$. This problem may appear due to too early activation of physiological mechanisms responsible for puberty, very often without known cause or because of the lesions in the central nervous system. It may be a reaction to an external hormonal stimulation (e.g. by food, drugs or cosmetics) or an internal one (e.g. ovarian or adrenal pathologies).

Early diagnosis and treatment of PP is essential due to emotional consequences (peer approval, problems of the puberty age, early fertility and motherhood) and effects on health (early termination of growing, decreased fertility in adulthood) ${ }^{(2)}$. The diagnostic algorithms of PP encompass hormonal, genetic and imaging examinations.

A standard imaging examination which extends the physical one is breast and abdominal ultrasound scan (US). Its aim is to visualize underlying changes that may be a cause (e.g. ovarian and adrenal tumor) and consequence (accelerated development of the reproductive organs uterine and ovaries) of precocious puberty.

\section{Technique of US examination in precocious puberty}

In order to perform appropriate ultrasound examination in a child, one needs to have an ultrasound system which apart from standard $2 \mathrm{D}$ projection in gray scale also enables the assessment of vascular flow (color, power and spectral Doppler modes). Harmonic imaging is frequently used and improves the quality of the obtained image.

Moreover, the apparatus must enable size assessment of examined structures (length and volume) and documentation of the examination in the form of video printer printouts or storing digital photographs and films in the memory of the system (or coupled computer).

Lack of cooperation of the examined child, agitation and fretfulness frequently make the examination considerably more difficult. The "cine" review option, enabling going back to the previously obtained images after freezing the image, helps to overcome such inconveniences.

Transducers used in the abdominal ultrasound examination of a child, particularly in the assessment of the organs located in the lesser pelvis, should be of various sizes and have a broad frequency spectrum. As a rule, younger children require the usage of smaller transducers with higher frequencies than older children.

The small pelvis is a region to which US access is hindered mainly due to intestinal loops, whose contents frequently "conceal" the organs we wish to visualize. Therefore, appropriate preparation of the patient for US examination 
Miednica mniejsza należy do przestrzeni o utrudnionym dostępie dla badania USG, głównie z powodu pętli jelitowych, których zawartość często „przesłania” interesujące nas narządy. $Z$ tego względu zaleca się odpowiednie przygotowanie pacjenta do ultrasonografii. Wypełniony pęcherz moczowy rozsuwa pętle jelitowe i stanowi okno akustyczne dla położonych za nim narządów, jednak u najmłodszych pacjentów niemożliwe jest utrzymanie wypełnionego pęcherza przez cały czas trwania badania. Również dieta ograniczająca ilość gazów w jelitach sprzyja lepszemu uwidocznieniu narządów miednicy.

\section{Rola badania USG w przedwczesnym dojrzewaniu płciowym}

Problemy związane z objawami przedwczesnego dojrzewania zmieniają się wraz z wiekiem dziecka. U najmłodszych dziewczynek najczęstszym wskazaniem do diagnostyki są torbiele jajników lub nadmiernie stymulowane, powiększone pęcherzyki jajnikowe, widoczne niekiedy już w badaniu prenatalnym. U niemowląt karmionych mlekiem matki często spotyka się również powiększenie piersi (jednoi obustronne $)^{(3)}$. Izolowany rozwój piersi u starszych dziewczynek wiązany jest ze zwiększoną wrażliwością receptorów estradiolowych w tkance gruczołowej, zewnątrz- lub wewnątrzustrojową zwiększoną podażą estrogenów oraz wczesnym pobudzeniem osi podwzgórze - przysadka mózgowa prowadzącym do prawdziwego przedwczesnego dojrzewania $^{(4)}$. U dziewcząt w wieku przedszkolnym rozwój drugorzędowych cech płciowych oraz wystąpienie pierwszej miesiączki należy zawsze różnicować z wczesnym wariantem prawidłowego dojrzewania, zmianami w centralnym układzie nerwowym, wtórną postacią przedwczesnego dojrzewania oraz zmianami izolowanymi.

\section{Ocena gruczołów piersiowych}

Przedwczesne powiększenie się gruczołów piersiowych może być zarówno składową PDP, jak i izolowanym problemem (izolowane przedwczesne thelarche). USG piersi pokazuje objętość tkanki gruczołowej, rozwój zatoki mlekowej oraz obecność i średnicę przewodów mlekowych. Powyższe dane pozwalają na zakwalifikowanie gruczołu piersiowego do poszczególnych faz jego rozwoju według skali Tannera ${ }^{(3)}$. Powiększenie piersi, zwłaszcza asymetryczne, może wynikać także z obecności zmian ogniskowych (najczęściej torbieli, nacieków zapalnych i ropni), naśladujących jedynie rozwój gruczołu. Uważa się ponadto, iż powiększenie piersi u niemowląt, jako skutek oddziaływania hormonów matki, może utrzymywać się do 12 miesięcy po porodzie i nie jest zjawiskiem patologicznym ${ }^{(3)}$.

\section{Ocena macicy}

Macica w badaniu USG widoczna jest typowo bezpośrednio ku tyłowi w stosunku do pęcherza moczowego, najczęściej w linii pośrodkowej. Przy odpowiednio wypełnionym pęcherzu moczowym jest ona w całości dostępna is recommended. A filled urinary bladder separates the intestinal loops and thus creates an acoustic window for the organs located behind it. However, in the youngest patients, maintaining the bladder filled for the entire duration of the examination is not feasible. The diet which reduces the amount of gas in the intestines also helps to visualize the pelvic organs.

\section{Relevance of US examination in precocious puberty}

The problems associated with precocious puberty change with the child's age. In the youngest girls, the most frequent indication for establishing a diagnosis are ovarian cysts as well as excessively stimulated and enlarged ovarian follicles that are sometimes visible in a prenatal examination. In infants fed with breast milk, uni- or bilateral breast enlargement may also be observed ${ }^{(3)}$. Isolated premature thelarche in older girls is associated with increased sensitivity of estradiol receptors in the glandular tissue, increased intraorganic or extracorporeal delivery of estrogens and early stimulation of the hypothalamic-pituitary axis leading to genuine precocious puberty ${ }^{(4)}$. In preschool girls, the development of secondary sex characteristics and menarche should always be differentiated from early variant of normal puberty, changes in the central nervous system, secondary form of precocious puberty and isolated changes.

\section{Assessment of mammary glands}

Premature enlargement of the mammary glands may be a sign of PP or an isolated problem (isolated premature thelarche). Breast ultrasound examinations demonstrate the volume of the breast tissue, development of the lactiferous sinus as well as presence and diameter of milk ducts. Such data allow for categorization of the glands to individual stages of their development according to the Tanner scale ${ }^{(3)}$. Breast enlargement, especially asymmetrical, may result from the presence of focal lesions (frequently cysts, inflammatory infiltrations and abscesses) which only mimic a developing gland. What is more, it is believed that breast enlargement in infants, resulting from the effects of the mother's hormones, may persist for up to 12 months following birth and is not a pathological phenomenon ${ }^{(3)}$.

\section{Assessment of the uterus}

On US examination, the uterus is typically visualized posteriorly to the urinary bladder, usually in the medial line. When the urinary bladder is adequately filled, the organ is entirely seen in the examination. To assess the uterus, both transverse and sagittal images are used (similarly to the bladder assessment). The length and thickness of the uterus are measured in the sagittal plane whereas the largest width is taken in the transverse image. The obtained measurements are used to calculate approximate uterine 
badaniu. W ocenie macicy stosuje się standardowo przekroje poprzeczne oraz strzałkowe (jak przy ocenie pęcherza moczowego). W przekroju strzałkowym dokonuje się pomiaru długości i grubości macicy, w przekroju poprzecznym mierzy się największą jej szerokość. Z uzyskanych pomiarów można wyliczyć przybliżoną objętość macicy. Prawidłowa długość macicy oraz jej objętość, przybierające wartości o szerokim zakresie i zmieniające się wraz $\mathrm{z}$ wiekiem dziewczynek, przedstawiono $\mathrm{w}$ tab. 1. Według niektórych autorów ${ }^{(5)}$ przyjęcie granicznej objętości, której nie może przekroczyć macica przed pokwitaniem, na poziomie $1,8 \mathrm{ml}$ pozwala na uzyskanie w diagnostyce PDP czułości i swoistości równych 100\% (tab. 1).

W okresie przedpokwitaniowym macica charakteryzuje się tubularnym lub stożkowym kształtem, grubość trzonu jest mniejsza lub równa grubości szyjki ${ }^{(7)}$. Zmiana tych proporcji (powiększenie trzonu macicy, która przybiera gruszkowaty kształt) jest objawem rozwoju tego narządu, powinna więc mieć miejsce w okresie okołopokwitaniowym.

Endometrium na przekroju strzałkowym w okresie przedpokwitaniowym nie jest widoczne lub przybiera postać linijnej, hiperechogenicznej struktury o grubości mniejszej niż $1 \mathrm{~mm}$. Pomiaru grubości endometrium dokonuje się w przekroju strzałkowym, w najgrubszym miejscu, mierząc łącznie dwie warstwy. Prawidłowa grubość błony śluzowej macicy u starszych dziewcząt przybiera różne wartości, wykazując dużą zmienność w przebiegu cyklu menstruacyjnego (4-16 mm $\left.{ }^{(8)}\right)$.

Innym parametrem używanym do określenia stopnia rozwoju wewnętrznych narządów płciowych jest analiza spektrum przepływu krwi w tętnicach macicznych. Wyróżnia się trzy typy przepływu krwi. Najczęstszy w okresie przedpokwitaniowym jest przepływ obecny wyłącznie $\mathrm{w}$ fazie skurczu serca z brakiem przepływu w rozkurczu. Okres pokwitania znajduje swoje odzwierciedlenie w stopniowym pojawianiu się przepływu krwi w fazie rozkurczu. U dojrzałych kobiet $\mathrm{w}$ tętnicach macicznych notuje się przepływ ciągły, obecny we wszystkich fazach cyklu pracy serca ${ }^{(9)}$.

\section{Ocena jajników}

Jajniki typowo położone są po obu stronach macicy, w praktyce spotyka się je w różnej lokalizacji. W celu ich

\begin{tabular}{|l|c|c|c|c|}
\hline \multirow{2}{*}{} & \multicolumn{4}{|c|}{$\begin{array}{c}\text { Grupa wiekowa } \\
\text { Age group }\end{array}$} \\
\cline { 2 - 5 } & $\begin{array}{c}\text { 1-6 lat } \\
\text { 1-6years }\end{array}$ & $\begin{array}{c}\mathbf{6 - 8} \text { lat } \\
\text { 6-8years }\end{array}$ & $\begin{array}{c}\mathbf{8 - 1 0} \text { lat } \\
8-10 \text { years }\end{array}$ & $\begin{array}{c}\text { 10-12 lat } \\
\text { 10-12 years }\end{array}$ \\
\hline $\begin{array}{l}\text { Długość macicy } \\
\text { (mm) } \\
\text { Uterine length (mm) }\end{array}$ & $28 \pm 4$ & $33 \pm 4$ & $35 \pm 7$ & $42 \pm 5$ \\
\hline $\begin{array}{l}\text { Objętość macicy } \\
\text { (ml) } \\
\text { Uterine volume }(\mathrm{ml})\end{array}$ & $1,9 \pm 0,5$ & $2,6 \pm 0,9$ & $3,4 \pm 1,1$ & $4,3 \pm 1,6$ \\
\hline
\end{tabular}

Tab. 1. Długość i objętość macicy w poszczególnych grupach wiekowych $^{(6)}$

Tab. 1. Length and volume of the uterus in individual age groups ${ }^{(6)}$ volume. The broad ranges of normal values of the uterine length and volume changing with girls' age are presented in tab. 1. According to some authors ${ }^{(5)}$, determining the limit volume at the level of $1.8 \mathrm{ml}$, which may not be exceeded before puberty, allows for obtaining $100 \%$ of sensitivity and specificity in PP diagnostics (tab. 1).

Before puberty, the uterus is tubular or conic in shape and the thickness of its corpus is lower or equal to the cervical thickness ${ }^{(7)}$. Alterations in these proportions (enlargement of the uterine body which becomes pearshaped) are a sign of uterine development, so they should occur in the peripubertal period.

In the prepubertal period, the endometrium is not visible in sagittal images or may be seen as a linear hyperechoic structure with maximum $1 \mathrm{~mm}$ in thickness. Measuring the thickness of the endometrium should be performed in the sagittal plane, at its thickest site by measuring two layers simultaneously. The normal thickness of the uterine endometrium in older girls varies and changes considerably in the course of the menstrual cycle $\left(4-16 \mathrm{~mm}^{(8)}\right)$.

Another parameter used to determine the development of the internal reproductive organs is the analysis of blood flow in the uterine arteries. There are three types of flow. The most frequent type in the prepubertal period is the flow that is seen solely in the systolic phase, but not observed in the diastolic one. The period of puberty is characterized by gradual appearance of diastolic blood flow. Finally, in adult women, a continuous flow, seen in all phases, is noted in the uterine $\operatorname{arteries}^{(9)}$.

\begin{tabular}{|c|c|}
\hline $\begin{array}{l}\text { Wiek dziecka } \\
\text { Age }\end{array}$ & $\begin{array}{c}\text { Średnia objętość jajnika (ml) } \\
\text { Mean ovarian volume }\end{array}$ \\
\hline $\begin{array}{l}0-1 \text { miesiąc } \\
0-1 \text { month }\end{array}$ & $0,5 \pm 0,4$ \\
\hline $\begin{array}{l}1-3 \text { miesiące } \\
1-3 \text { months }\end{array}$ & $0,4 \pm 0,1$ \\
\hline $\begin{array}{l}3 \text { miesiące }-1 \text { rok } \\
3 \text { months }-1 \text { year }\end{array}$ & $0,5 \pm 0,2$ \\
\hline $\begin{array}{l}1-3 \text { lata } \\
1-3 \text { years }\end{array}$ & $0,7 \pm 0,4$ \\
\hline $\begin{array}{c}3-5 \text { lat } \\
3-5 \text { years }\end{array}$ & $0,7 \pm 0,5$ \\
\hline $\begin{array}{c}5-7 \text { lat } \\
5-7 \text { years }\end{array}$ & $0,8 \pm 0,6$ \\
\hline $\begin{array}{l}\text { 7-9 lat } \\
7-9 \text { years }\end{array}$ & $0,6 \pm 0,4$ \\
\hline $\begin{array}{l}\text { 9-11 lat } \\
9-11 \text { years }\end{array}$ & $1,3 \pm 1,0$ \\
\hline $\begin{array}{l}11-13 \text { lat } \\
11-13 \text { years }\end{array}$ & $3,7 \pm 2,1$ \\
\hline $\begin{array}{l}\text { 13-15 lat } \\
13-15 \text { years }\end{array}$ & $6,7 \pm 4,8$ \\
\hline
\end{tabular}

Tab. 2. Średnia objętość jajnika u dziewczynek $w$ poszczególnych grupach wiekowych ${ }^{(5)}$

Tab. 2. Mean ovarian volume in girls at various ages ${ }^{(5)}$ 
uwidocznienia, zwłaszcza w niesprzyjających warunkach badania (niedostatecznie wypełniony pęcherz moczowy, gazy w pętlach jelitowych), należy wielokrotnie, w różnych płaszczyznach „przeszukiwać” jamę miednicy. Po uwidocznieniu jajników dokonuje się pomiaru w trzech prostopadłych płaszczyznach, oblicza objętość oraz notuje przybliżoną ilość pęcherzyków oraz średnicę pęcherzyka dominującego. Wielkość jajników oraz ich wewnętrzna echostruktura zmieniają się wraz z wiekiem. Średnią objętość jajnika w poszczególnych grupach wiekowych podano w tab. 2.

Objętość zarówno macicy, jak i jajników można mierzyć za pomocą aplikacji aparatu USG, dokonujących automatycznych kalkulacji objętości z badania trójwymiarowego.

Struktura wewnętrzna jajnika w zależności od stopnia rozwoju może być zakwalifikowana do jednego z czterech typów ${ }^{(6)}$ :

- typu 1., jednorodnego - nie stwierdza się obecności pęcherzyków;

- typu 2., ubogopęcherzykowego - widocznych jest mniej niż 6 pęcherzyków o średnicach nieprzekraczających 10 mm;

- typu 3., wielopęcherzykowego - stwierdza się więcej niż 6 pęcherzyków o średnicach do $10 \mathrm{~mm}$;

- typu 4., wielkopęcherzykowego - widoczny jest co najmniej 1 pęcherzyk o średnicy większej lub równej $10 \mathrm{~mm}$.

Częstość występowania poszczególnych typów budowy jajników w poszczególnych grupach wiekowych przedstawia tab. 3.

Jedną z przyczyn obwodowej postaci przedwczesnego dojrzewania dziewcząt jest hormonalnie czynna torbiel jajnika. Może ona przybierać postać klasycznej, bezechowej przestrzeni płynowej ewidentnie związanej z jajnikiem. Bywa, że obraz nie jest łatwy do interpretacji. Torbiele mogą mieć obraz zbliżony do zmiany litej, bywają też tak duże, że nie sposób jednoznacznie określić punktu wyjścia, kontaktują się bowiem z nerką, trzustką, a nawet śledzioną czy wątrobą.

Przyczyną wystąpienia objawów przedwczesnego dojrzewania mogą być również guzy jajnika (np. guz z komórek warstwy ziarnistej, gonadoblastoma) ${ }^{(10)}$, przybierające postać zmian litych, torbielowatych lub mieszanych, najczęściej

\section{Assessment of the ovaries}

The ovaries are typically located at two sides of the uterus but in practice, they may be found in various localizations. In order to visualize them, particularly when the conditions are unfavorable (insufficiently filled bladder, gas in the intestines), one should "search" for them in the pelvis repeatedly and in various planes. When the ovaries have been visualized, their measurements are taken in three perpendicular planes and their volume, approximate number of follicles as well as the diameter of the dominant follicle are calculated. The size of the ovaries and their internal echostructure change with age. The mean ovarian volume in various age groups is presented in table 2 .

The volume of both the uterus and the ovaries can be measured using applications of the US apparatus which make automatic volume calculations on the basis of a three dimensional image.

Depending on the stage of development, the internal structure of the ovary may be classified to one of four groups ${ }^{(6)}$ :

- type 1 - homogeneous - no follicles are detected;

- type 2 - paucicystic - less than 6 follicles are visible with diameters not exceeding $10 \mathrm{~mm}$;

- type 3 - multicystic - more than 6 follicles are detected with diameters of up to $10 \mathrm{~mm}$;

- type 4 - macrocystic - at least one follicle is visible that is greater than or equal to $10 \mathrm{~mm}$.

The mean ovarian volume in various age groups is presented in table 3 .

One of the reasons for peripheral precocious puberty in girls is a hormonally active ovarian cyst. It may be a classical, anechoic fluid area visibly adjoining the ovary. Sometimes, however, the image is not easy to interpret. Cysts may resemble solid lesions. They may be so large that their place of origin is impossible to be unequivocally determined since they remain in contact with the kidney, pancreas or even with the spleen or liver.

The reason for symptoms of precocious puberty may also be ovarian tumors (e.g. tumor made of granulosa cells, gonadoblastoma $)^{(10)}$ which may be solid, cystic or of mixed type and are usually visibly connected with the ovary.

\begin{tabular}{|c|c|c|c|c|}
\hline & $\begin{array}{l}\text { Typ } 1 . \\
\text { Type } 1\end{array}$ & $\begin{array}{l}\text { Typ } 2 . \\
\text { Type } 2\end{array}$ & $\begin{array}{l}\text { Typ } 3 . \\
\text { Type } 3\end{array}$ & $\begin{array}{l}\text { Typ } 4 . \\
\text { Type } 4\end{array}$ \\
\hline $\begin{array}{l}\mathbf{1 - 6} \text { lat } \\
1-6 \text { years }\end{array}$ & $78 \%$ & $13 \%$ & $9 \%$ & - \\
\hline $\begin{array}{l}\mathbf{6 - 8} \text { lat } \\
6-8 \text { years }\end{array}$ & $65 \%$ & $20 \%$ & $15 \%$ & - \\
\hline $\begin{array}{l}\mathbf{8 - 1 0} \text { lat } \\
8-10 \text { years }\end{array}$ & $61 \%$ & $16 \%$ & $19 \%$ & $4 \%$ \\
\hline $\begin{array}{l}\mathbf{1 0}-\mathbf{1 2} \text { lat } \\
10-12 \text { years }\end{array}$ & $44 \%$ & $11 \%$ & $28 \%$ & $17 \%$ \\
\hline
\end{tabular}

Tab. 3. Częstość występowania poszczególnych typów budowy jajników w różnych przedziatach wiekowych (wzorowane na(5))

Tab. 3. Frequency of occurrence of individual ovarian structure types in different age groups (based on $\left.{ }^{(5)}\right)$ 
wyraźnie związanych z jajnikiem. W różnicowaniu z powikłaną torbielą pomocne bywa uwidocznienie wewnętrznych segmentów naczyniowych w badaniu dopplerowskim. Brak przepływu naczyniowego może być jednak skutkiem skrętu guza, o czym należy pamiętać zwłaszcza w sytuacji, gdy badanie dotyczy pacjenta z ostrymi objawami brzusznymi.

\section{Ocena nadnerczy}

Kolejnym narządem, którego patologie mogą prowadzić do wystąpienia objawów przedwczesnego dojrzewania, są gruczoły nadnerczowe, prawidłowo widoczne u niemowląt i małych dzieci jako pasmowate struktury o warstwowej, harmonijnej budowie. U starszych dzieci struktura staje się coraz mniej widoczna, w końcu u dorosłych w badaniu USG ocenia się wyłącznie pola nadnerczowe, gdyż sam narząd przestaje być widoczny. Należy opisać wszelkie zmiany ogniskowe (np. torbiele, guzy), a także powiększenie czy pofałdowanie (tzw. obraz kory mózgowej), a pacjenta skierować do dalszej diagnostyki.

\section{Ocena innych narządów}

Istnieje ponadto grupa chorób, które imitują objawy przedwczesnego dojrzewania płciowego. Zaliczyć do niej można np. wspomniane wcześniej powiększenie piersi na skutek zmiany ogniskowej czy też sugerujące przedwczesne menarche krwawienie z dróg rodnych, które może wynikać z obecności zmian nowotworowych w pochwie (np. rhabdomyosarcoma). Guzy zlokalizowane w okolicy sklepień pochwy są doskonale widoczne w przezbrzusznym badaniu USG w okolicy zapęcherzowej. Pozostałe lokalizacje takich zmian mogą wymagać badania z dostępu przez krocze.

\section{Podsumowanie}

Badanie USG piersi i narządów jamy brzusznej powinno być elementem standardowego postępowania diagnostycznego u każdego dziecka z objawami przedwczesnego dojrzewania płciowego. Powinno obejmować opis struktur istotnych dla kierującego na badanie endokrynologa, tj. stopnia rozwoju i obecności ewentualnych zmian patologicznych w obrębie gruczołów piersiowych, określenie objętości macicy i jajników w odniesieniu do norm dla wieku, ocenę obecności i grubości endometrium, opis struktury, wielkości i obecności ewentualnych zmian ogniskowych w nadnerczach.

Uwidocznienie jakichkolwiek zmian w obrazie USG sugerujących PDP u pacjentów diagnozowanych z innych powodów musi skutkować zaleceniem konsultacji endokrynologicznej, wydanym już w gabinecie USG i zapisanym we wnioskach $\mathrm{z}$ badania.
To differentiate such lesions from a complicated cyst, it is helpful to visualize the internal vascular segments in a Doppler examination. No signs of flow may, however, result from torsion of the tumor which should be considered especially when examining a patient with acute abdominal symptoms.

\section{Assessment of the adrenal glands}

Another organ whose pathologies may lead to symptoms of precocious puberty is the adrenal gland. In infants and young children, adrenal glands are normally visible as bands with layered, harmonic structure. In older children, this structure becomes less and less visible. In adults, only suprarenal areas are assessed since the organ itself remains invisible. A physician ought to describe all focal lesions (e.g. cysts, tumors) as well as enlargement or excessive folding of adrenals (so-called, image of the cerebral cortex) and the patient should be referred to further diagnosis.

\section{Assessment of other organs}

Furthermore, there is a group of diseases which mimic symptoms of precocious puberty, for example, the aforementioned breast enlargement due to a focal lesion or vaginal bleeding which being suggestive of premature menarche may in fact result from the presence of neoplastic lesions in the vagina (e.g. rhabdomyosarcoma). Tumors localized in the region of the vaginal fornices are well visible in abdominal US examinations in the retrovesical region. To determine the presence of such lesions in other localizations a transperineal ultrasound examination may be necessary.

\section{Conclusion}

Breast and abdominal US examinations should constitute an element of standard diagnostic procedure in each child with symptoms of precocious puberty. It should include the assessment of structures that are essential for the referring endocrinologist, i.e. the degree of development and possible presence of pathological lesions within the mammary glands, determining uterine and ovarian volumes with respect to norms for a given age, assessment of the presence and thickness of the endometrium as well as description of the structure, size and possible presence of focal lesions in the adrenal glands.

Detection of any changes in a US image that are suggestive of PP in patients diagnosed for other pathologies must entail the referral to an endocrinologist issued in the physician's office and included in the conclusions from the examination. 


\section{Konflikt interesów}

Autor nie zgłasza żadnych finansowych ani osobistych powiazań z innymi osobami lub organizacjami, które mogtyby negatywnie wptynać na treść publikacji oraz rościć sobie prawo do tej publikacji.

\section{Piśmiennictwo/References}

1. Chittwar S, Shivprakash, Ammini AC: Precocious puberty in girls. Indian J Endocrinol Metab 2013; 16 (Suppl 2): S188-S191.

2. Lazar L, Meyerovitch J, de Vries L, Phillip M, Lebenthal Y: Treated and untreated women with idiopathic precocious puberty: long-term followup and reproductive outcome between the third and fifth decades. Clin Endocrinol (Oxf) 2013. DOI: 10.1111/cen.12319.

3. Chung EM, Cube R, Hall GJ, González C, Stocker JT, Glassman LM: From the archives of the AFIP: breast masses in children and adolescents: radiologic-pathologic correlation. Radiographics 2009; 29: 907-931.

4. Uçar A, Saka N, Baş F, Bundak R, Günöz H, Darendeliler F: Is premature thelarche in the first two years of life transient? J Clin Res Pediatr Endocrinol 2012; 4: 140-145.

5. Haber HP, Mayer EI: Ultrasound evaluation of uterine and ovarian size from birth to puberty. Pediatr Radiol 1994; 24: 11-13.

\section{Conflict of interest}

Author does not report any financial or personal links with other persons or organizations, which might affect negatively the content of this publication and/or claim authorship rights to this publication.

6. Badouraki M, Christoforidis A, Economou I, Dimitriadis AS, Katzos G: Sonographic assessment of uterine and ovarian development in normal girls aged 1 to 12 years. J Clin Ultrasound 2008; 36: 539-544.

7. Eksioglu AS, Yilmaz S, Cetinkaya S, Cinar G, Yildiz YT, Aycan Z: Value of pelvic sonography in the diagnosis of various forms of precocious puberty in girls. J Clin Ultrasound 2013; 41: 84-93.

8. Jakubowski W. (ed.): Pomiary w ultrasonografii. Seria Wydawnicza Praktyczna Ultrasonografia, Warszawa - Zamość 2004.

9. Ziereisen F, Heinrichs C, Dufour D, Saerens M, Avni EF: The role of Doppler evaluation of the uterine artery in girls around puberty. Pediatr Radiol 2001; 31: 712-719.

10. Iliev DI, Ranke MB, Wollmann HA: Mixed gonadal dysgenesis and precocious puberty. Horm Res 2002; 58: 30-33.

Klinika Neonatologi

i Intensywnej Terapii Noworodka

Warszawskiego Uniwersytetu Medycznego

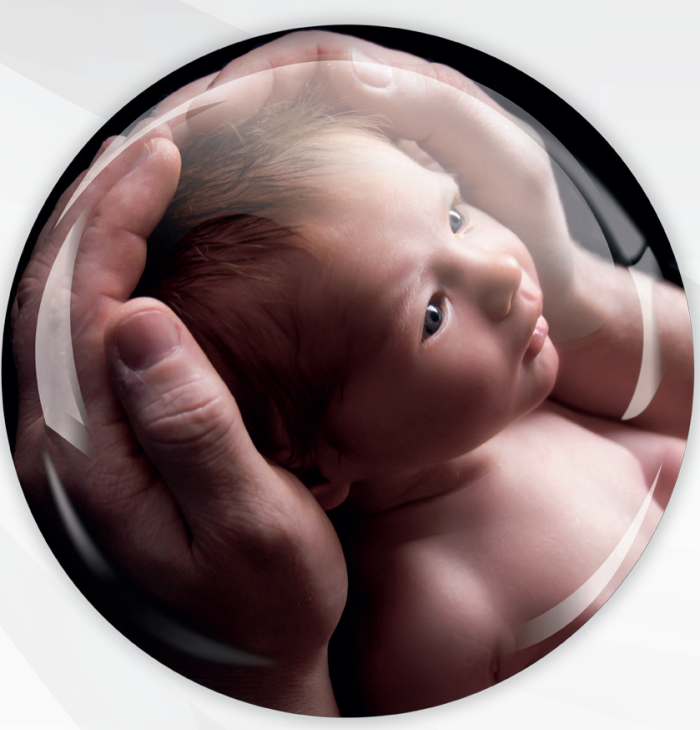

Zakład Radiologii Pediatrycznej

Warszawskiego Uniwersytetu Medycznego

16-17 maja 2014 r.

\section{Toruń • Hotel Filmar}

Konferencja odbywa się pod patronatem

Polskiego Towarzystwa

Neonatologicznego 